\title{
Reorganizing Hospital Space: The 1894 Plague Edpidemic in Hong Kong and the Germ Theory*
}

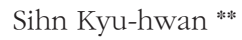

1. Introduction

2. The Hong Kong Plague Epidemic and Quarantine Measures

1) Lowson's Understanding of the Plague

2) The Genealogy of Public Health Theory in Colonial Hong Kong

3. The Formation and Reorganization of Hospital Space

1) The Government Civil Hospital and Disease Classification

2) William Hunter's Bacteriological Study

3) Reorganization of Tungwah Hospital and Preliminary Isolation Ward System

4. Conclusion

\section{Introduction}

The 1894 plague epidemic in Hong Kong was one of the record-breaking events in the history of disease and medicine in East Asia for several

\footnotetext{
* This work was supported by the Ministry of Education of the Republic of Korea and the National Research Foundation of Korea (NRF-2015S1A5A2A03048654).

** Dept. of Medical History \& Institute for History of Medicine, College of Medicine,

Yonsei University, Seoul, KOREA

E-mail: jerryq@yuhs.ac
} 
Sihn Kyu-hwan : Reorganizing Hospital Space: The 1894 Plague Edpidemic in Hong Kong and the Germ Theory

reasons. First, its range: the plague, which originated in China's Yunnan and Gunagxi Provinces, spread to Hong Kong in 1894 and then to other locations in East Asia and the Pacific rim-Macao in 1895, Taiwan in 1896, India in 1896-98, San Francisco in 1899, and Australia in 1900-03-killing 22 million people. Second, it erupted at the height of bacteriology's "golden age" after the pioneering developments in the field, by Louis Pasteur and Robert Koch in the 1880s. The plague bacillus was discovered in Hong Kong in 1894 by Alexandre Yersin (1863-1943) and Kitasato Shibasaburō (1852-1931), laying the foundation on which vaccines and treatments could be developed. Third, the plague epidemic significantly impacted Hong Kong society. The deadly contagious disease devastated Hong Kong society for three decades, from 1894 to 1923 , infecting 21,867 people and killing 20,489, with a mortality rate of $93.7 \%$ (Choa, 1993: 129).

The 1894 plague quarantine was regarded as a turning point in the history of public health in Hong Kong. Quarantine officer James Alfred Lowson (1866-1935) remarked that for three months from early May to late July in 1894 the contagious disease infected 2,679 people and killed 2,485 , with a mortality rate of $93.4 \%$ (Lowson, 1895: 29). The outbreak of the disease led to the introduction of Western medicine into Hong Kong society, inducing the colonial authority to strengthen prevention and control of plague epidemic.

While avoiding an explanation that emphasizes the superiority of Western medicine, this work concentrates on two points. First, previous research has analyzed the 1894 Hong Kong plague as a confrontation between Eastern and Western medicine a conflict between nationalism and colonialism (Li, 2013). According to these works, the preventive measures taken by the colonial authorities are rational and reasonable, while those taken by 
Sihn Kyu-hwan : Reorganizing Hospital Space: The 1894 Plague Epidemic in Hong Kong and the Germ Theory

the Chinese are uncivilized and passive. In the eyes of many Europeans and Americans, the plague was enough to mark China as a hygienically "backward" country that continued to incubate a "medieval" disease in the modern era (Benedict, 1996: 166). Even the preventive measures taken by Hong Kong's colonial authorities who were regarded by the Chinese as violent and destructive are deemed to have been the only effective measure, taken by "Unsung Hero" (Choa, 1993: 145). However, neither the colonial authorities nor the Western medical world could identify the route of infection, and therefore neither produced effective preventive vaccines or treatments. In this regard, in order to determine whether the preventive measures taken by the Hong Kong's colonial authorities were legitimate, this paper examines how they, and the medical world, understood the disease.

Second, the focus of most prior research has been on the impact of germ theory upon medical space. Sutphen and Echenberg emphasized only the introduction and development of germ theory after the 1894 Hong Kong plague (Sutphen, 1997; Echenberg, 2002). Cunningham pointed out the transformation of the meaning of plague took place in the laboratory space (Cunningham, 1992: 224). The germ theory of disease, which was an important outcome of laboratory medicine in the late 19th century, attributed the cause of diseases to contact between independent organisms, not to cell mutation or environmental factors. This understanding of disease was entirely different from that of miasma theory, which focused on environmental factors. Since the introduction of germ theory, equipment and facilities for bacteriological examination were required to confirm a diagnosis. Disease classication and alteration of hospital space resulted from implementing bacteriological criteria. We can confirm the 
Sihn Kyu-hwan : Reorganizing Hospital Space: The 1894 Plague Edpidemic in Hong Kong and the Germ Theory

reorganization cases of the urban and hospital space after the introduction of germ theory by municipal authorities and social reformers in East Asia. While Oliver R. Avison (1860-1956), the director of Severance Hospital, reorganized hospital space through the bacteriological classification of disease and laboratory medicine in Seoul in 1900s, John B. Grant (18901962) and Huang Zifang (1899-1940) tried to reform urban and everydaylife space through the Health District Office in Beijing in 1920s (Sihn, 2008; 2015). Then, how did germ theory have an influence on the reorganization of urban and hospital space in Hong Kong? This paper investigates to explain the correlation between the plague epidemic and hospital spaces in Hong Kong in the late 19th century in order to help understand the growth of modern hospitals in Hong Kong as well as East Asia in general.

\section{The Hong Kong Plague Epidemic and Quarantine Measures}

1) Lowson's Understanding of the Plague

The plague started from Yunnan Province in China in 1893 and moved to Guangzhou in early February of 1894. Upon hearing the news that an infectious disease had occurred in Guangzhou between mid-March and early May in 1894, the Hong Kong's colonial authorities dispatched James A. Lowson, an acting superintendent of Government Civil Hospital, to Guangzhou on May 4. On May 6, he saw a plague patient in a Chinese hospital in Guangzhou. On May 7, he returned to Hong Kong. On May 8, he saw a patient named Ahong who was hospitalized in the Government Civil Hospital due to remittent fever; Lowson suspected that Ahong had the plague and quarantined him (Choa, 1993: 132-133). ${ }^{1)}$ This patient was a

1) James A. Lowson, "Bubonic Plague," 16 May 1894, enclosed in Robinson to Ripon, 
Sihn Kyu-hwan : Reorganizing Hospital Space: The 1894 Plague Epidemic in Hong Kong and the Germ Theory

hospital worker. He was the first confirmed patient of the outbreak of the plague in Hong Kong.

In the morning of May 10, Lowson visited the Taipingshan area and nearby Tungwah Hospital, where he confirmed a diagnosis of plague for 20 patients. Tungwah Hospital had been opened for the Chinese in February 1872 and provided traditional Chinese medicine, with support from the private sector and the authorities. In the afternoon, he submitted a report regarding the matter to the Sanitary Board. Lowson included the following five measures in the report. First, the drain of every house should be cleaned and disinfected. Second, the house of any patient should be disinfected. Third, the clothes of the infected and their family members should be disinfected. Fourth, patients must not gather in the Tungwah Hospital under any circumstance because it would inevitably lead to the spread of the disease. Fifth, Hygeia, the quarantine ship, should be moved from the coast to the center of the harbor immediately. If Chinese delegations were to board the ship and persuaded that the patients would be in the charge of their own countrymen, it would not be difficult to move Chinese patients to the ship (Ayres and Lowson, 1894: 15).

In May 10, 1894, Governor Sir William Robinson (1836-1912, term of Service: 1891-1898) officially recognized the outbreak of the plague in Hong Kong and convened a Sanitary Board meeting. The person in charge of the Sanitary Board was Registrar General J. H. Stewart Lockhart. Colonial Surgeon Philip Bernard Chenery Ayres (1840-1899, term of Service: 18731897) was in charge of the colony's hygiene administration, and Lowson was

(May 17, 1894), Great Britain, Colonial Office, Original Correspondence: Hong Kong, 1841-1951, Series 129 (hereafter CO 129)/263, pp.49-50; Hong Kong Telegraph, (May 11, 1894). 
Sihn Kyu-hwan : Reorganizing Hospital Space: The 1894 Plague Edpidemic in Hong Kong and the Germ Theory

a working-level manager (Choa, 1993: 130). Lowson argued that infected patients should be quarantined on Hygeia as a strong quarantine measure and that each house should be inspected and disinfected. However, officials on the Sanitary Board, such as Ho Kai (1859-1914) expressed his concern that strong quarantine measures conducted by government forces might cause offense to the Chinese. ${ }^{2)}$

On May 11, the Sanitary Board convened a special meeting to announce "Preventive Measures against the Plague" under Article 32 of the "1887 Public Health Regulation," allowing the "Permanent Committee" to exercise its full power to take quarantine measures to keep the disease away. The committee appointed legal advisor John Joseph Francis as chair (Greenwood, 1986: 17-45), engaging Chief of Police F. H. May and Colonial Surgeon P. B. C. Ayres. ${ }^{3)}$ While the Permanent Committee was legally responsible for quarantine administration, the quarantine measures were Ayres's responsibility. John Mitford Atkinson (1856-1917), the superintendent of the Government Civil Hospital, was in charge of quarantine, and Lowson was an assistant superintendent.

On May 12, although there was resistance from the Chinese, the Permanent Committee directed the quarantine authority to move plague patients in the Tungwah Hospital to Hygeia and conducted house-to-house inspections and disinfection work. On May 13, on-board isolation began. On May 14, an isolation hospital was set up in Kennedy Town Barrack

2) "Minutes of the Proceedings of the Sanitary Board, at a meeting held on Thursday, the $10^{\text {th }}$ day of May, 1894," Hong Kong Government Gazette (May 26, 1894), pp.487-488; Hong Kong Telegraph, (May 11, 1894).

3) "Minutes of the Proceedings of the Sanitary Board, at a special meeting held on Friday, the $11^{\text {th }}$ day of May, 1894," Hong Kong Government Gazette (May 26, 1894), p.488; China Mail, May 12, 1894. 
Sihn Kyu-hwan : Reorganizing Hospital Space: The 1894 Plague Epidemic in Hong Kong and the Germ Theory

Hospital. On May 24, another isolation hospital was set up in a glass factory in Kennedy Town. By May 22, 393 people were diagnosed with the plague of whom 320 died (Choa, 1993: 133-134).

\section{Figure 1. British Troops Destroying the Refuse from Infected Houses at Taipingshan (IIlustrated London News from a photograph by D. K. Griffith)}

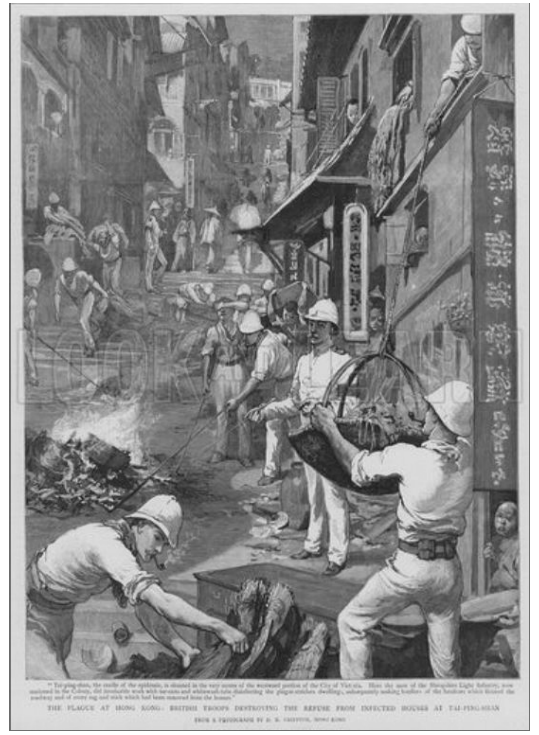

(Source: "The Plague at Hong-Kong," Illustrated London News, July 28, 1894)

On May 23, the colonial authorities mobilized 300 light infantry to conduct a house-to-house inspection near the Taipingshan (Platt eds., 1998). The house-to-house inspection was indispensable in finding new patients and the dead, to isolate the infected or bury the dead and to clean and disinfect contaminated areas. But it did face the strongest resistence from the Chinese. The colonial authorities had the hardest time inspecting households because of the closed structure of Chinese houses. To make 
Sihn Kyu-hwan : Reorganizing Hospital Space: The 1894 Plague Edpidemic in Hong Kong and the Germ Theory

matters worse, Chinese officials and traditional Chinese doctors did not cooperate with the authorities. In the meantime, the colonial authorities found five dead people and four plague patients (Ayres and Lowson, 1894: 10). On May 31, the Permanent Committee revised legislation to demolish or close inappropriate housing facilities. As a result, Kauyupong, Xinhingli, Ngachoihong, and Meilunli in the Taiping Mountain area were devastated. The colonial office in London forced the Hong Kong authorities to close the Tungwah Hospital.

Despite these efforts by the colonial authorities, the disease spread to other areas with up to 100 new patients being infected daily. The colonial authorities mobilized military forces to conduct house-to-house inspections and to impose a forced quarantine. The Chinese, however, refused to transfer patients to Hygeia. In their view, it could be a signal indicating the control by the foreigners using Western medicine. The Chinese wanted to be treated in the Tungwah Hospital. They were shocked by the fact that house-to-house inspections were being conducted by the military and did not think the plague could be treated by Western medicine. There was even a rumor that Western doctors used the eyebrows or livers of children to treat the plague. The continuous resistance from the Chinese resulted in the colonial authorities using the glass factory in Kennedy Town as a branch hospital of the Tungwah Hospital. ${ }^{4)}$

However, Lowson did not trust the Tungwah Hospital. After finding out the first plague patient in Government Civil Hospital, he witnessed 20 more plague patients in the Tungwah Hospital only two days later. He blamed the Tungwah Hospital for not even being able to diagnose the

4) "Correspondence from Robinson to Lord Ripon," (May 23, 1894), CO 129/263/122. 
Sihn Kyu-hwan : Reorganizing Hospital Space: The 1894 Plague Epidemic in Hong Kong and the Germ Theory

disease. He also criticized the health officials and even the governor of the colony harshly for neglecting their duties to quarantine the plague. ${ }^{5)}$ In 1892, Lowson started working as a doctor in the Government Civil Hospital run by the Hong Kong's colonial authorities. Back then, the hospital was under the charge of Atkinson, but since Atkinson was on a business trip to London at the time the plague spread rapidly, Lowson, who was 28 years old, became the temporary superintendent (Choa, 1993: 130-131).

As the person in charge of an isolation ward for plague sufferers, Lowson took quarantine measures for three months. His understanding of the epidemic and measures taken were well illustrated in a report released in Budapest in July 1894. He believed the disease occured due to the dirty and overcrowded environment in China. He focused on drainage, lighting, ventilation, and human waste in Chinese residences. He believed the Hong Kong plague, like the Guangzhou plague, was caused by the dirty and overcrowded environment in which the Chinese lived. While the population in Hong Kong had more than doubled, from 122,120 in 1873 to 210,995 in 1893 , its hygienic conditions had not improved that much (Ayres and Lowson, 1894: 9). Lowson confirmed the first case of the Hong Kong plague and conducted spot investigations of the Taipingshan area where the patient and Chinese population resided. He reported that the Taipingshan area was densely populated and dirty, without ventilation or water and waste-removal systems, creating favorable conditions for the outbreak of the disease. In addition, the Chinese did not receive proper treatment in the early stages of infection. Lowson found that 2,447 people out of 2,619 had died from the plague in the three months from May to July

5) James A. Lowson, "Bubonic Plague," 16 May 1894, enclosed in Robinson to Ripon, (May 17, 1894), CO 129/263. 
Sihn Kyu-hwan : Reorganizing Hospital Space: The 1894 Plague Edpidemic in Hong Kong and the Germ Theory

1894. Among Westerners, by contrast, two people out of 11 infected died, and among the Japanese, six out of ten died. He concluded that it was the poor treatment in the initial stages that led to the high mortality rate among the Chinese (93.4\%) compared to that for Westerners (18.2\%) and Japanese (60\%) (Lowson, 1895: 28-30). According to the study conducted by Aoyama Tanemichi during the same period, the mortality rates were $1.66 \%$ and 54.5\% for the British and Japanese, respectively. For the Chinese, it was 70\% in the Kennedy Town Hospital and 80-90\% in the Tungwah Hospital (Aoyama, 1894: 44-45).

In the early stage of the epidemic, Lowson did not think the plague was caused by a plague bacillus. He even believed that the plague was not contagious and that the disease might not have been introduced from Guangzhou. ${ }^{6}$ ) He thought that the most important way to prevent plague was to sanitize the environment. He was unable and unwilling to conduct microscopic examinations. Plague patients could only be detected by symptoms, and prevention of the spread of the disease was to be achieved by wiping out dirty living conditions, such as incineration of the clothes and furniture of patients, demolition of residences, and imposition of quarantine.

Lowson pointed out the Chinese residences near the Taipingshan area and the Tungwah Hospital as sources of infection. In a report submitted on May 17, 1894, Lowson suggested a "Hygienic and Medical Perspective regarding the Tungwah Hospital." He argued that the Tungwah Hospital was the hotbed of the plague, threatening Hong Kong's public health and therefore should be closed down immediately. As an alternative, he

6) Hong Kong Telegraph, (May 11, 1894). 
Sihn Kyu-hwan : Reorganizing Hospital Space: The 1894 Plague Epidemic in Hong Kong and the Germ Theory

suggested the construction of a new hospital run by Westerners (Lowson, 1895: 32-34).

Amid Lowson's struggles, the plague epidemic in Hong Kong drew attention from scientists around the world. On June 12 and 15, Kitasato Shibasaburō and Alexandre Yersin arrived in Hong Kong, and Lowson said that they each found a plague bacillus, on June 14 and 23, respectively. Lowson believed that Kitasato was the one who first found the plague bacillus. Lowson warmly welcomed Kitasato, who become a worldrenowned scientist after he succeeded in cultivating a tetanus bacillus and developing a serum, and provided him with support for his study. However, he did not help Yersin, who was a French scientist in competition with the United Kingdom in East Asia. While Kitasato was provided with a cadaver from Lowson and focused on finding a plague bacillus in its blood and internal organs, Yersin, who received nothing, succeeded in separating a plague bacillus from a lymph gland (Solomon, 1997: 60-61). Since scientists did not discover that the plague bacillus lived in rat fleas, this isolation of the bacillus was a major breakthrough in determining the route of infection. Yersin experimented with routes of infection in various sources, such as mice, flies, and soil. The argument that bubonic plagues were caused through rat fleas was first made by Paul-Louis Simond (18581947) in 1898, and the rat-flea theory was officially confirmed by the British Plague Commisssion in Bombay in 1907 (Petrie, 1908: 97-112).

Lowson, a strong advocate of the miasma theory in the early stages of the plague's quarantine, did not reject Kitasato's germ theory. He even said that the cause of the plague was attributable to infection with a plague bacillus. Even so, while Lowson was an ardent supporter of Kitasato, he also protected the miasma theory. Rather, he argued that environmental 
Sihn Kyu-hwan : Reorganizing Hospital Space: The 1894 Plague Edpidemic in Hong Kong and the Germ Theory

factors, such as overcrowding, dirt caused by lack of drainage, poor ventilation and light, and malnutrition were to blame for the disease. In conclusion, Lowson believed that Kitasato's germ theory strengthened his miasma theory.

\section{2) The Genealogy of Public Health Theory in Colonial Hong Kong}

Colonial Surgeon P. B. C. Ayres, who was in full charge of quarantine in the Hong Kong plague, was born in Oxfordshire, in the United Kingdom, in July 1840. He graduated from University of Edinburgh Medical School in August 1865 and worked as a government surgeon in Mauritius and India. After arriving in Hong Kong in November 1873, he worked as Colonial Surgeon and the director of the government hospitals for 24 years. He was in charge of the police hospital, the military hospital, the Government Civil Hospital, Tungwah Hospital, Victoria Prison, the Mental Hospital, Lock Hospital, and the Colonial Ministry of Health. It was in the 1860s, when Ayres was still studying medicine, that Edwin Chadwick's Public Health Act and the miasma theory took their hold. As a faithful apostle of Chadwick's Public Health Act, Ayres led Hong Kong's hygiene health care policy in the late 19th century (Hong Kong Museum of Medical Sciences Society, 2006: 87).

John M. Atkinson (1887-1912) was born in Cambridge in 1887. He graduated from the Royal College Medical School in 1878 and received a Ph.D. in health science from Cambridge University in 1894. In November 1887, he came to Hong Kong as a manager at Hong Kong’s Government Civil Hospital. He worked in Hong Kong for 25 years, until retirement in 1912. As a bacteriologist, he had a great interest in bacteriology and published his research in the Lancet and the British Medical Journal. However, during the 
Sihn Kyu-hwan : Reorganizing Hospital Space: The 1894 Plague Epidemic in Hong Kong and the Germ Theory

1894 outbreak, he was in the United Kingdom for his Ph.D. thesis, so he could not participate in the quarantine work. ${ }^{7)}$ As a supervisor and de facto head of Hong Kong's Government Civil Hospital, Atkinson was interested in operating a bacteriological laboratory. However, he did not prepare for a bacteriological laboratory and was likely not to lead laboratory medicine in Hong Kong.

James A. Lowson was born in Forfar, Scotland, in July 1866, and received Bachelor of Medicine from the University of Edinburgh Medical School in 1888, when he was 22 years old. He went to Hong Kong in 1892 and worked as a doctor at the Government Civil Hospital. He was a manager at the hospital during the 1894 epidemic in Hong Kong and was in charge of quarantine activities. Like Ayres, he was a faithful apostle of Chadwick and advocated strong quarantine administration based on the miasma theory (Choa, 1993).

While the germ theory was spreading in the 1880s, medical circles in the United Kingdom were still influenced by Chadwick's Public Health Act and the miasma theory. In 1842, Chadwick wrote a report titled "Report on the Sanitary Condition of the Labouring Poor," putting emphasis on preventive measures and improvements to residential environments rather than on the treatment of disease. The report led to the enactment of the Public Health Act in 1848. The Public Health Act stipulated that improvements to residential environments were important to the prevention of disease, on the basis that environmental improvements could help curb the outbreak or spread of a disease. Chadwick's theory influenced not just the United Kingdom but also colonial management. From 1851 to the 1900s, the

7) “John Mitford Atkinson, M.B. Lond,” British Medical Journal 1(June 16, 1917), p. 2946. 
Sihn Kyu-hwan : Reorganizing Hospital Space: The 1894 Plague Edpidemic in Hong Kong and the Germ Theory

United Kingdom focused on improving residential environments and environmental hygiene in the colonies as part of its colonial management (Xue et al, 2012: 549-568).

Having found that urban sanitation had not improved in Hong Kong, the British government directed Osbert Chadwick (1844-1913), a civil engineer and the son of Edwin Chadwick to report on the hygienic status of Hong Kong. In July 1882, he submitted a report titled "Report on the Sanitary Conditions of Hong Kong." He explained in the report that Hong Kong's sanitary conditions posed a serious threat to public health and that a complete overhaul of the city's construction was required. His point was that overcrowded and isolated places served as a hotbed of disease (Chadwick, 1882: 18). His argument was adopted by the Hong Kong colonial authority and served as momentum to revise the "Public Health Ordinance" in 1887. Subsequently, under the regulation of the act, density and ventilation had to be taken into consideration when erecting new buildings.

Ayres, who worked as a colonial government official in Hong Kong for 24 years, from August 1873, knew Chadwick's Public Health Act better than anyone (Faure, 2005: 10-19). Even at the end of the 19th century, when the germ theory started to take root in Germany and France, Chadwick's Public Health Act and the miasma theory were firmly established in the United Kingdom. Chadwick and his son were strongly determined to improve residential environments and hygienic conditions to prevent diseases and improve health conditions, and their influence was strong both in the United Kingdom and Hong Kong. Ayres and Lowson, who were in charge of sanitation in Hong Kong, were also Chadwick's apostles. Ayres highly praised Osbert Chadwick's report, which supported the argument he had 
Sihn Kyu-hwan : Reorganizing Hospital Space: The 1894 Plague Epidemic in Hong Kong and the Germ Theory

made for the previous decade. ${ }^{8)}$ Ayres, Atkinson and Lowson, who were advocates of miasma theory, readily accepted the germ theory of plague in part because they could easily transpose miasma theory onto germ theory and had not felt the need to change already existing routine preventive measures. The discovery of Yersina pestis in 1894 resulted in a turning point in the application of germ theory in Hong Kong. William Hunter, the first bacteriologist in Hong Kong, made new geneology of germ theory in Hong Kong.

\section{The Formation and Reorganization of Hospital Space}

1) The Government Civil Hospital and Disease Classification

Hong Kong's first government hospital was built in January 1841, when the British army occupied Hong Kong. It was not long before the hospital was destroyed by typhoons, and the British army used a hospital ship as its hospital. In 1843, Sir Henry Pottinger was appointed Governor of Hong Kong, and he appointed Dr. Alex Anderson as the first Colonial Surgeon, in charge of hygiene and medical care in Hong Kong. The United Kingdom recommended that the colonial government refrain from intervening in medical issues, but in 1849, the Hong Kong's colonial authorities established the Government Civil Hospital in the Central area of Hong Kong Island. In its first year, it treated 195 patients of which 18 died. In the second year, 222 were treated and 18 died. According to a report by a colonial surgeon in 1854, a total of 180 people (59 Europeans, 89 Indians, and 32 Chinese)

8) PBC Ayres, “Colonial Surgeon's Report 1882," The Hong Kong Government Gazette, (March 21, 1883). 
Sihn Kyu-hwan : Reorganizing Hospital Space: The 1894 Plague Edpidemic in Hong Kong and the Germ Theory

used the hospital in 1853.9) It was a small two-story wooden building, which was used temporarily. It was destroyed by typhoons in September $1874 .{ }^{10)}$

In November 1874, the Government Civil Hospital was relocated to the Hotel d'Europe on Hollywood Road near the Central Police Station and operated there temporarily. ${ }^{11)}$ Ayres, who was a director of the Government Civil Hospital and Lock Hospital, wanted to build a large new hospital where he could combine operations of the two. When the temporary building of the Government Civil Hospital burned down in December 1878, Lock Hospital in the Saiyingpun area was used as the Government Civil Hospital. In July 1880, a new hospital was built in Lock Hospital, and the Government Civil Hospital got to use most of the part of the old and new buildings of Lock Hospital. As compulsory examination of prostitutes was abolished in September 1887, the Lock Hospital was transformed into a woman's hospital and then merged with the Government Civil Hospital in 1894 .

9) “The Colonial Surgeon's Report, 1853," The Hong Kong Government Gazette, (April 29, 1854), pp.116-117.

10) The Hong Kong Government Gazette, (October 17, 1874), p.576; Hong Kong Museum of Medical Sciences Society, Plague, SARS and the Story of Medicine in Hong Kong (Hong Kong: Hong Kong University Press, 2006), pp.85-88.

11) The Hong Kong Government Gazette, (November 21, 1874), p. 660. 
Sihn Kyu-hwan : Reorganizing Hospital Space:

The 1894 Plague Epidemic in Hong Kong and the Germ Theory

Figure 2. Government Civil Hospital \& Superintendent's House in Hong Kong (1893)

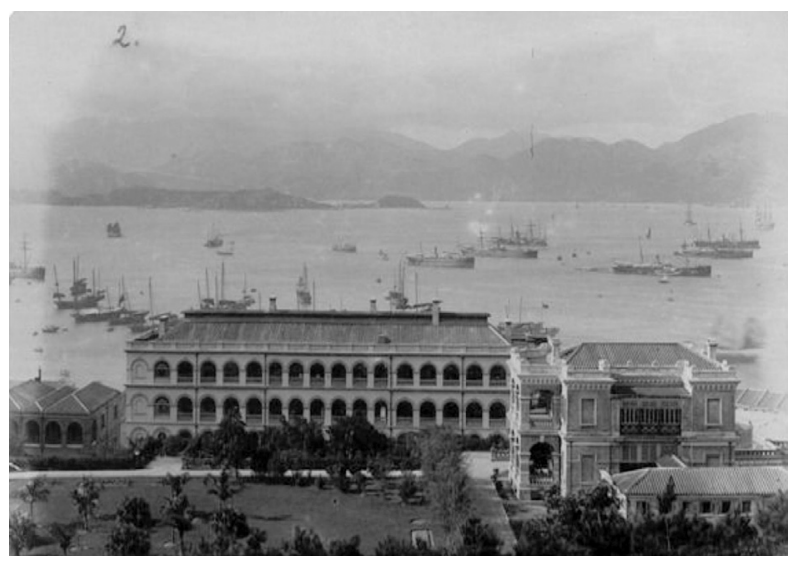

(Source: Colonial Office Photographic Collection)

The new hospital in 1880 was a two-story masonry building with 16 archshaped windows. The second floor was divided into three areas by two walls facing each other, with a capacity of 30 beds, ten in each area. The first floor was used as a doctor's office, another office, and a residence. ${ }^{12)}$ In 1889, a three-story building was built. As an official residence was built for the hospital's staff in the same year, additional beds were located on the first and third floors of the building. As a result, a total of 100 beds were installed in the hospital. The number of inpatients in the hospital increased from 1,055 in 1880 to 1,793 in 1889(Ayres, 1890: 306). This was a Western-style building, in which lighting and ventilation were optimized, creating favorable conditions for treating patients with infectious disease. Hugh McCallum (1853-1898) was appointed as a pharmacist and analyst

12) C. J. Wharry, "Government Civil Hospital," The Hong Kong Government Gazette, (April 22, 1881). 
Sihn Kyu-hwan : Reorganizing Hospital Space: The 1894 Plague Edpidemic in Hong Kong and the Germ Theory

in November 1879; he established a laboratory when Lock Hospital was opened in July $1880 .{ }^{13)}$ He was responsible to examine the quality of water, toxicity, and food. ${ }^{14)}$

Before the 1880s, there was no germ inspection room in the Government Civil Hospital or Lock Hospital, run by the colonial authorities. After the late 1880s, pharmacists and analysts, such as Hugh McCallum, Edward Crow, and Malcolm Watson, ran laboratories in the Government Civil Hospital. However, they carried out water-purity control, poison inspection, and food inspection, not germ inspection. ${ }^{15)}$

Atkinson took charge of the Government Civil Hospital in 1888, and he established a laboratory and a mortuary there in 1889. ${ }^{16)}$ The spatial organization of the new hospital was totally different from that of previous hospitals. The new hospital included not just a laboratory and a mortuary but also an operating room, an infectious disease room, and a vaccination room. In order to see if the new space of the hospital has changed the character of hospital space, it is necessary to examine what kind of disease classification proceeded in the new hospital.

Until the 1880s, colonial surgeons divided the diseased by symptoms, not by bacteriological tests. Atkinson became a superintendent of the Government Civil Hospital in 1888. In 1890, Ayres directed him to analyze the causes of death for 1,793 patients who died in the Government Civil

13) Hugh McCallum, "Laboratory, Government Civil Hospital," The Hong Kong Government Gazette, (February 1, 1881), p.660.

14) J. Wharry, "Government Civil Hospital," The Hong Kong Government Gazette, (May 21, 1883).

15) Edward Crow, "Report of the Government Analyst," The Hong Kong Government Gazette, (July 13, 1889).

16) “Colonial Surgeon's Annual Report, 1888," The Hong Kong Government Gazette, (July 13, 1889), p. 574 . 
Sihn Kyu-hwan : Reorganizing Hospital Space: The 1894 Plague Epidemic in Hong Kong and the Germ Theory

Hospital (Ayres, 1890: 311-316). It turned out that major causes of death included general diseases, local diseases, poison, injuries, and surgical operations. General diseases were divided into diseases dependent on morbid poisons, diseases dependent on external agents, developmental diseases, and unclassified diseases. The diseases dependent on morbid poisons and diseases dependent on external agents were again divided into the following five subcategories: The first subcategory comprised of smallpox, cowpox, chickenpox, measles, rose rash, scarlet fever, dengue fever, typhus, plague, recurrent fever, influenza, whooping cough, mumps, diphtheria, schistorrachis, simple continued fever, typhoid/pseudotyphoid, cholera/suspected cholera/Asiatic cholera/epidemic cholera, sporadic cholera symonyms sporadic cholera/simple cholera/cholera nostras, epidemic diarrhea, and dysentery. The second subcategory consisted malaria and beriberi. The third subcategory included phagedenic ulcer, erysipelas, pyemia, and septicemia. The fourth was comprised of syphilis and gonorrhea. Finally, the fifth subcategory consisted of rabies, glanders, horsepox, and splenic fever. Local diseases included nervous system diseases; eye, nose, mouth, and circulatory diseases; respiratory diseases; digestive system diseases; lymphatic system diseases; thyroid diseases; supra renal capsules; urological diseases; genital diseases; and diseases of the female breast, male breast, locomotorium, connective tissue, and skin.

In Western medicine, diseases were classified on the basis of environmental factors, the body system, and whether a patient was infected. While disease classification methods had changed slightly since the 1870s, they still focused on infection, fever, and body system. The cause of death also focused on mainly symptoms by looking at body parts, diseases of systems, and whether a patient was infected. Regardless of 
Sihn Kyu-hwan : Reorganizing Hospital Space: The 1894 Plague Edpidemic in Hong Kong and the Germ Theory

how much Atkinson was interested in bacteriology, the existing disease classification was still used in official reports. In the 1890s, the Government Civil Hospital prepared with the hardware needed to change the hospital space, but the hospital gave a lukewarm response in bacteriological disease classification and space utilization.

\section{2) William Hunter's Bacteriological Study}

After the plague outbreak in 1894, Hong Kong suffered from periodic outbreak of plague. After the germ theory of plague was accepted, the Hong Kong's colonial authorities were not interested in what the plague bacilli were but in where they could be found and how to prevent and control an outbreak of the disease (Sutphen, 1997: 111-112). As the Hong Kong economy had no lasting improvement, Governor Sir Henry A. Blake (1840-1918, term of Service: 1898-1903) decided to take drastic measures. He requested that the Colonial Office send an experienced bacteriologist for plague control in April 1901. ${ }^{17)}$ In November 1901, the British government dispatched William Hunter (1875-1909) to Hong Kong.

William Hunter was born in Banffshire, Scotland, in 1875. In 1897, he graduated from the Aberdeen University with top honors. After graduation, he studied pathology at the Universities of Berlin and Aberdeen University, conducting pathology examinations and bacteriological studies in London Hospital Medical College. In 1901, he was appointed as a government surgeon of the British government, placed in charge of bacteria tests and autopsies. Since there was no germ laboratory in Hong Kong at the time, he hesitated to go Hong Kong. When the colonial authorities promised

17) "Henry A. Blake to Joseph Chamberlain"(12th June, 1901), CO 129/305, p. 353. 
Sihn Kyu-hwan : Reorganizing Hospital Space: The 1894 Plague Epidemic in Hong Kong and the Germ Theory

support for bacteriological apparatus and laboratory, he accepted his appointment. On arriving in Hong Kong, he established a temporary laboratory in the Kennedy Town Infectious Diseases Hospital. However, due to damages sustained by the bacteriological apparatus on the way to Hong Kong, Hunter's laboratory was delayed for four months (Hong Kong Museum of Medical Sciences Society, 2006: 147-151).

The first mission Hunter received was to analyze causes of death. From March of 1902, he started analyzing cause of death on the basis of bacteriological characteristics. In 1902, Hunter examined the causes of death for 2,816 people. Major causes of death included general diseases (27 cases), local diseases (43 cases), and injuries (5 cases). The 27 cases of general disease included major infectious diseases and other diseases. Smallpox, the plague, typhoid, cholera, dysentery, beriberi, malaria, malarial cachexia, septicemia, tetanus, Hansen's disease, acquired syphilis, congenital syphilis, tuberculosis, alcoholism, anemia, nervous breakdown, famine, burn, premature birth, Hodgkin's disease, opiumism, stillbirth, drown, death by hanging, suffocation, and athrepsia were found as causes for 1,636 deaths. Of these, 473 people had the plague, followed by 379 with cholera and 151 with tuberculosis. Local diseases were divided into nervous system diseases, circulatory diseases, respiratory diseases, digestive system diseases, lymphatic system diseases, urological diseases, and reproductive system diseases. A total of 1,099 people had local diseases, including pneumonia (in 141 people), diarrhea of unknown cause (in 102 people), tuberculosis bronchopneumonia (in 100 people), and injuries (in 81 people). Hunter's major disease classification was conducted through a microscopic examination (Hunter, 1903: 213-216).

His second mission was to confirm mice as a source of plague, and thus 
Sihn Kyu-hwan : Reorganizing Hospital Space: The 1894 Plague Edpidemic in Hong Kong and the Germ Theory

he carried out bacteriological examinations on mice. Although Hong Kong had witnessed Alexandre Yersin's successful isolation of bacillus, general acceptance that rats were the vectors of Yersina pestis did not readily come. In 1897, Ogata Masanori suggested that blood-sucking insects like the mosquito or flea were a likely vector of plague. The next year, the French scientist Paul-Louis Simond became the first to demonstrate that plague was transmitted from rat to rat and from rat to human. In 1901, the first Indian Plague Commission discussed that the medium of transference of plague from rats to man is through the agency of fleas but did not reach any definitive conclusion. Between 1902 and 1903, French scientists supported the rat-flea theory, but British doubts persisted (Echenberg, 2007: 69-70). At that time, Hunter was not interested in the rat-flea theory and promoted the transmission of plague by the food and household utensils. As Dr. Charles M. Heanley who participated in the Bacteriological Institute and investigated the rat-flea theory in April 1906, Hunter also accepted the ratflea theory (Hunter, 1907: 477). Hunter's contribution to the history of antiplague measures was to institutionalize bacteriological examinations on all mice in Hong Kong. To do this, Hunter prepared a post-mortem room and microscope room in the old Coroner's Court adjoining the Government Public Mortuary. The Coroner's Court consisted of two fair sized rooms. One was a rat post-mortem room, the other was a microscope or research room. The systematic examination of rats found alive or dead was begun when he assumed charge of the Government Public Mortuary on the 20th March, 1902 (Hunter, 1903: 221). From this moment, bacteriological examinations on mice became systematized in Hong Kong. During the months of March, April and May, these examinations were carried out by himself. From May of 1902, bacteriological examinations were conducted by 
Sihn Kyu-hwan : Reorganizing Hospital Space: The 1894 Plague Epidemic in Hong Kong and the Germ Theory

four Japanese doctors on all mice found in the colony. The job was passed on to three Chinese doctors from the College of Medicine in Hong Kong after the Japanese doctors returned to Japan in October. Bacteriological examinations on 400 mice were conducted on a daily basis. A total of 117,839 were examined in one year, and the plague bacillus was found in 2,015 mice (Hunter, 1903: 221-222).

Hunter's third mission was to elucidate the relation between animal disease and the plague. In the Annual Report of the Medical Department for 1898, Atkinson drew attention to the fact that outbreaks of what was known as rinderpest in cattle had preceded the epidemic of 1894, 1896, and 1898. On the arrival of Dr. Hunter and Prof. Simpson, Atkinson suggested they study the susceptibility of animals to plague infection. They investigated animal plague in Daily Farm and Kennedy Town slaughterhouses and demonstrated that pigs, calves, sheep, monkeys, and fowls were more or less susceptible to plague of a fatal nature. Hunter continued his investigations and reached the following conclusions: First, the plague in Hong Kong is the bubonic plague with rats being the vector of transmission. Second, plague is spread chiefly through the digestive system. People must be careful of the possibility of food infection. Third, animals such as cats, fowls, calves, sheep, and pigs are susceptible to plague infection. Plague is primarily epizootic and within a week or two becomes epidemic in man. Fourth, Hunter raises the possibility of the occurrence of latent cases of plague in human beings (Hunter, 1904b: iii-iv). Judging from these facts, preventive measures for the plague needed to encompass animals as well as human beings.

Hunter's fourth mission was to construct the base and system for bacteriological examinations. He could not establish a bacteriological 
Sihn Kyu-hwan : Reorganizing Hospital Space: The 1894 Plague Edpidemic in Hong Kong and the Germ Theory

laboratory in the Government Civil Hospital, and the conditions at the temporary laboratory in the Kennedy Town Infectious Diseases Hospital were poor. There was no accommodation provided for researchers, and the laboratory was located far from the Government Vaccine Institute and the Government Public Mortuary, making it difficult for researchers to develop vaccines and conduct autopsies. Only after a construction site for the Bacteriological Institute was secured near the Taipingshan area was it anticipated that bacteriological examinations could be conducted properly (Hunter, 1903: 212).

As Hunter became director of the Government Vaccine Institute in October 1902, he wanted to combine post-mortem, development of vaccine, and bacteriological examinations. To manage disease control more efficiently and optimize his sphere of activity, Hunter needed "a properly equipped and centrally situated Bacteriological Institute" from the outside of hospital (Hunter, 1903: 212). In September 1903, the colonial authorities approved the plan for the Bacteriological Institute to unify disease control work. By early 1904, Hunter narrowly acquired new public mortuary buildings at Hill Road. In addition to the main autopsy room, there was a room for examination of rats for plague surveillance and smaller rooms for research (Hong Kong Museum of Medical Sciences Society, 2006: 161).

The Bacteriological Institute opened for routine bacteriological and research work on 15 March 1906. The Bacteriological Institute was designed by Messrs. Leigh and Orange who supervised its construction. They occupied 20,776 square feet $\left(1,390 \mathrm{~m}^{2}\right)$ and consisted of a main building and two subsidiary buildings. The main building contained a basement, ground floor and upper floor, and afforded the following accommodation: four laboratories, a library, a combined waiting room and office, a photographic 
Sihn Kyu-hwan : Reorganizing Hospital Space: The 1894 Plague Epidemic in Hong Kong and the Germ Theory

room and a spare room, a store room, an incubating room, a heating chamber and refrigerating room, besides a hall and staircase, a small-dark room, lavatories, etc. One of the subsidiary buildings, a one-story building, afforded accommodation for 11 Chinese attendants, with kitchen, the other, a two-story building, contained a stable (four stalls and two loose boxes); houses for five cattle and eight calves; two sheep-pens and suitable accommodation for monkeys, fowls, rats, mice, guinea pigs and rabbits. There was also a room for four Chinese attendants, a doctor's room, a corn store and a fodder store. All the buildings were of red brick, built in lime mortar and pointed externally in cement mortar. The main building was plastered internally, and subsidiary buildings were pointed internally in plaster. Because each room had a high ceiling and large windows, it was suitable for the lighting and ventilation. The cement concrete and mortar of buildings improved appearance and hygiene (W. Chatham, 1906: 548). The Bacteriological Institute ideally combined spaces for post-mortem, development of vaccine, and bacteriological examinations with these infrastructure facilities. This formation and arrangement of space realized Hunter's intentions to manage urban space from the perspective of germ theory.

3) Reorganization of Tungwah Hospital and Preliminary Isolation Ward System

The Tungwah Hospital was the first Chinese hospital in Hong Kong operated by Chinese with Chinese medicine, opening on 14 February 1872. It consisted of four individual, two-storeyed buildings. A central building contained the director's hall, doctors' accommodation, and business offices. Three hospital wards had a capacity of 80 to 100 patients. A vaccinator 
Sihn Kyu-hwan : Reorganizing Hospital Space: The 1894 Plague Edpidemic in Hong Kong and the Germ Theory

and three Chinese doctors resided in the Hospital with Chinese medicine. The lower ward were intended for poorer gratis patients while the upper storey, better lighted and ventilated, was reserved for paying ones. The wards were divided into wooden stalls, each containing two beds - matted wooden platforms with white wadded quilts as bedding (Sinn, 2003: 50-51; He Peiran, 2010: 49)

The center of the central building was called Great House, a multi-purpose space for meeting and discussion. In the vicinity of Great House were a consulting room, a doctor's room, a night-duty room, and administrative offices. The number of beds in the hospital increased from 80 in 1872 to 142 in 1903. The first floor had three hospital wards with a surgical ward of 24 beds in the south side and two general wards of 54 beds in the north and west side. The second floor had 64 beds in the north and west side. A dispensary and a mortuary located in the south of hospital (He Peiran, 2010: 49)

As the 1894 plague epidemic spread, the colonial authorities pointed out the Tungwah Hospital as a hotbed of plague. The Tungwah Hospital tried to transform hospital space into a Western-medicine-style under the threat of abolition. The Tungwah Hospital expanded an external mortuary into nearly thirty percentage of the size of the hospital and grew a flower garden on the west side of hospital. However, there were no bacteriological laboratory, post-mortem room, and operating room. Rather, the Tungwah Hospital internally pushed ahead with a Receiving Ward System (Shouzhengfang zhidu), a kind of preliminary isolation ward. While a patient visited the hospital, s/he selected his/her attending physician whose name was written on a paper chosen by lot. The doctor diagnosed the patient with Chinese medicine, and hospitalization was determined 
Sihn Kyu-hwan : Reorganizing Hospital Space: The 1894 Plague Epidemic in Hong Kong and the Germ Theory

in accordance with diagnostic outcome (Tung Wa Hospital Commission, 1896: evidence, 25).

After the plague outbreak, when a resident surgeon diagnosed a patient with Western medicine, the patients were arranged into the Receiving Ward categorized by diagnosis. Finally, the Inspecting Medical Officer of the colonial authorities diagnosed the patient in Receiving Ward, and the doctor rearranged the the patient for the second isolation ward. A hospital worker asked the patient to choose between Western medicine and Chinese medicine, and in that way the method of treatment was determined (Inspecting Medical Officer, 1898). Because there were no bacteriological laboratory and post-mortem room in the hospital, this kind of Receiving Ward System is inevitable. Many patients complained of what they perceived as unnecessary interference by the Western doctor and the hospital worker, but the Tungwah Hospital Commission argued for the necessity of Receiving Ward System for the management of infectious disease (Tung Wa Hospital Commission, 1896: xiii). Receiving Ward System in the Tungwah Hospital was the symbol of the reorganization of hospital space for the introduction of Western medicine and the management of infectious disease. However, the Tungwah Hospital did not promote the fundamental reorganization of hospital space, and was continuously affected by the external influence.

\section{Conclusion}

The 1894 Hong Kong plague epidemic served as a turning point in the history of the plague, the history of medicine in Southeast Asia, and Hong Kong's modern history. However, the quarantine measures taken by the 
Sihn Kyu-hwan : Reorganizing Hospital Space: The 1894 Plague Edpidemic in Hong Kong and the Germ Theory

colonial authorities were neither a clear-cut victory for Western medicine nor for a rational quarantine based on scientific medical knowledge. Hong Kong's medical officials depended on Edwin Chadwick's Public Health Act (1848) and Osbert Chadwick's "Public Health Ordinance” (1887), which had significant effects on sanitary administration in the United Kingdom and its colony in the mid-19th century. Chadwick's quarantine measures, based on the miasma theory, were about wiping out dirty living conditions and improving water supply and drainage facilities to prevent infectious diseases. Such measures were not meaningless in that they worked for cholera, a waterborne disease, to a certain extent. However, they were not effective in quarantining the plague.

For the bubonic plagues, quarantine needed to be implemented on the assumption that the infection was transmitted through rat fleas and that the patient had a respiratory infection. Focusing only on house-tohouse inspections and forced quarantine or isolation, without encouraging people to wear masks and without conducting disinfection, could expose hands-on workers to danger of infection, resulting in poor quarantine effectiveness. In this regard, while Lowson's quarantine measures were strongly accompanied by military power, they were capable of causing a backlash from patients and those who received an examination with unproven effectiveness. Nevertheless, Hong Kong's public medical officials stuck to the existing quarantine measures. They burned and tore down infected areas and forcibly put people who might have been infected under quarantine. On the one hand, these measures were the results of the miasma theory and environmental hygiene reform movement that dominated the United Kingdom and its colony for 50 years in the mid-19th century, and besides Britain's scientific community was out of the sphere of influence of 
Sihn Kyu-hwan : Reorganizing Hospital Space: The 1894 Plague Epidemic in Hong Kong and the Germ Theory

France and Germany as the center of germ theory of disease; on the other hand, they were caused by the reluctance by medical authorities to accept the latest medical knowledge. While Hong Kong's health officials were interested in new medical knowledge, they were lukewarm about applying them to policies.

It was in June 1894, when the world's most renowned bacteriologists such as Yersin and Kitasato started studying bacteriology in Hong Kong, that quarantine measures taken by Hong Kong's colonial authority took a new turn. The plague was no longer understood in terms of the miasma theory but through the use of the microscope and germ theory. Even after Hong Kong plague spread, the Hong Kong's colonial authorities were not interested in what plague bacilli were but in where they were to be found and how to prevent and control an outbreak of the disease. The anti-disinfection measures based on miasma theory were sometimes powerful and effective because of their strict and brutal ways. However, miasmatic measures had limitations that were difficult to maintain its effects because it caused a lot of manpower and costs such as environmental improvement and pollution removal. On the contrary, the bacteriological preventive measures required new personnels with knowledge of bacteria and equipments. As the Hong Kong economy had no lasting improvement, Governor Sir Henry A. Blake could not delay the bacteriological measures any longer. He requested that the United Kingdom dispatch a bacteriologist to Hong Kong to control the infectious disease in October 1901. In February 1902, bacteriologist William Hunter arrived in Hong Kong. He needed “a properly equipped and centrally situated Bacteriological Institute" from the outside of hospital, and wanted to combine post-mortem, development of vaccine, and bacteriological examinations. The Bacteriological Institute 
Sihn Kyu-hwan : Reorganizing Hospital Space: The 1894 Plague Edpidemic in Hong Kong and the Germ Theory

would realize Hunter's intentions to manage urban space from the perspective of germ theory.

The germ theory brought significant changes to the disease classification system. Until the 1890s, Hong Kong's colonial authority had classified cause of death mainly on the basis of symptoms, infectious diseases, parts of the body and diseases of systems. Microbiological analysis of the cause of death in Hong Kong was started by Hunter, a bacteriologist, in 1902. He used bacteriological tests with a microscope to analyze the cause of death. New disease recognition and medical recognition brought large changes to hospital space as well. In particular, from the 1880s to the early 1900s, Western medical circles witnessed shifts from miasma theory to the germ theory, thereby influencing Hong Kong's hospital spaces.

As the germ theory took ground in Hong Kong in 1894, the bacteriological laboratory and isolation ward became inevitable facilities, and hospital space were reorganized accordingly. However, the colonial authorities and local elites' strategy was different. As a government bacteriologist, Hunter established a central facility to unify several laboratories and to manage urban space from ouside the hospital. On the contrary, the Tungwah Hospital tried to transform hospital space with isolation ward and Receiving Ward System as the eclectic form of Chinese and Western medicine. The 1894 Hong Kong plague promoted the introduction of germ theory and the reorganization of hospital space.

Keywords: Hong Kong Plague Epidemic, Government Civil Hospital, Tungwah Hospital, Germ Theory, the Reorganization of Hospital Space, William Hunter 
Sihn Kyu-hwan : Reorganizing Hospital Space: The 1894 Plague Epidemic in Hong Kong and the Germ Theory

\section{REFERENCES}

1. Primary Sources

China Mail

Hong Kong Telegraph

Hong Kong Government Gazette

Annual Report of the Inspecting Medical Officer of the Tung Wa Hospital for 1897 (Hong Kong, 1898).

“Correspondence from Robinson to Lord Ripon,” (23th May, 1894), Great Britain, Colonial Office, Original Correspondence: Hong Kong, 1841-1951, Series 129 (hereafter CO 129)/263/122

G. F. Petrie, "A Short Abstract of the Plague Commission's Work in Bombay with Regard to the rat-flea theory," Transactions of the Royal Society of Tropical Medicine and Hygiene 2-2 (November 1908).

"Henry A. Blake to Joseph Chamberlain” (12th June, 1901), CO129/305

James A. Lowson, "Bubonic Plague," 16 May 1894, enclosed in Robinson to Ripon, 17 May 1894, CO 129/263

James A. Lowson, Medical Report: Hong Kong, the Epidemic of Bubonic Plague in 1894 (Hong Kong: Noronha \& Company, 1895).

Osbert Chadwick, Mr. Chadwick's Reports on the Sanitary Conditions of Hong Kong (Colonial Office, Nov. 1882).

P. B. C. Ayres and James A. Lowson, Report on the Outbreak of Bubonic Plague in Hong Kong, 1894 (Budapest: International Congress of Hygiene and Demography, July 1894).

PBC Ayres, The Colonial Surgeon's Report for 1889 (27th June, 1890).

Tung Wa Hospital Commission, Report of the Commission, Appointed by His Excellency Sir William Robinson, K. C.M. G., to Enquire into the Working and Organization of the Tung Wa [sic] Hospital, together with the Evidence taken before the Commission, and other Appendices (Hong Kong: Government Printer, 1896).

William Hunter, Report of the Government Bacteriologist for the Year 1902 (14th April, 1903).

William Hunter, Report of the Government Bacteriologist for the Year 1903 (1904a).

William Hunter, A Research into Epidemic and Epizootic Plague (Hong Kong: Noronha 
Sihn Kyu-hwan : Reorganizing Hospital Space: The 1894 Plague Edpidemic in Hong Kong and the Germ Theory

\& Co. Government and General Printers and Publishers, 9th June 1904b).

William Hunter, Report of the Government Bacteriologist for the Year 1904 (1905).

William Hunter, Report of the Government Bacteriologist for the Year 1905 (1906).

William Hunter, Report of the Government Bacteriologist for the Year 1906 (14th April, 1907).

W. Chatham, Report of the Director of Public Works, for the Year 1905 (1906).

Aoyama Tanemichi(靑山扸通), The Plague Report in Hong Kong(香港ニ於ヶル「ペスト」 調查ノ略報), (1894.11)。

\section{Secondary Sources}

Benedict, Carol. Bubonic Plague in Nineteenth-Century China (Stanford: Stanford University Press, 1996).

Choa, Gerald."The Lowson Diary: A Record of the Early Phases of the Bubonic Plague Epidemic in Hong Kong 1894," Journal of the Hong Kong Branch of the Royal Asiatic Society, 33 (1993).

Coleborne, Catharine and Angela McCarthy, "Health and Place in Historical Perspective: Medicine, Ethnicity, and Colonial Identities," Health and History 14 (2012).

Cunningham, Andrew R., "Transforming Plague: the Laboratory and the Identity of Infectious Disease," in Cunningham, A. R. and P. Williams, eds., The Laboratory Revolution in Medicine (Cambridge: Cambridge University Press, 1992).

Echenberg, Myron, Plague Ports: The Global Urban Impact of Bubonic Plague 18941901 (New York and London: New York University Press, 2007).

Echenberg, Myron, "Pestis Redux: The Initial Years of the Third Bubonic Plague Pandemic, 1894-1901," Journal of World History 13-2 (Fall 2002).

Faure, David, "The common people in Hong Kong history: their livelihood and aspirations until the 1930s," in Lee Pui-Tak ed., Colonial Hong Kong and Modern China: Interaction and Reintegration (Hong Kong: Hong Kong University Press, 2005).

Fung Chi-ming, A History of Queen Mary Hospital Hong Kong, 1937-1997 (Hong Kong: Queen Mary Hospital, 1997).

Greenwood, Walter, "John Joseph Francis, Citizen of Hong Kong, A Biographical Note," Journal of the Hong Kong Branch of the Royal Asiatic Society 26 (1986).

He Peiran ed., Donghuayiyuande Chuangliyu Yanjiin (The Establishment and Evolution 
Sihn Kyu-hwan : Reorganizing Hospital Space: The 1894 Plague Epidemic in Hong Kong and the Germ Theory

of Donghua Hospital) (Hong Kong: Joint Publishing, 2010).

Hong Kong Museum of Medical Sciences Society, Plague, SARS and the Story of Medicine in Hong Kong (Hong Kong: Hong Kong University Press, 2006).

Li Pui-tak, "Colonialism versus Nationalism: The Plague of Hong Kong in 1894," The Journal of Northeast Asian History 10-1 (Summer 2013).

Peckham, Robert, "Hong Kong Junk: Plague and the Economy of Chinese Things," Bulletin of the History of Medicine 90-1 (Spring 2016).

Platt, Jerome J., Maurice E. Jones, and Arleen Kay Platt, eds., The White Wash Brigade (London: Dix Noonan Webb, 1998).

Sihn Kyu-hwan, Gukga, Doshi, Wisaeng: 1930nyeondae Beipingshijengbu ui Wisaenghaengjeng gwa Gukgauiryo (State, City, and Health: Health Administration and State Medicine of Beiping municipality in the 1930s) (Seoul, Acanet, 2008).

Sihn Kyu-hwan, "Geundae Byeongwon Geonchukui Gonggan Byeonhwawa Seonggyeok (The Transformation of Space and the Characteristics of Hospital Buildings in Modern Korea)," Yeoksawa Gyeonggye (History and Boundary) 97 (December 2015).

Sinn, Elizabeth, Power and Charity: A Chinese Merchant Elite in Colonial Hong Kong (Hong Kong: Hong Kong University Press, 2003).

Solomon, Tom, "Hong Kong, 1894: the role of James A. Lowson in the Controversial Discovery of the Plague Bacillus," The Lancet 350 (July 1997).

Sutphen, Mary P., "Not What, but Where: Bubonic Plague and the Reception of Germ Theories in Hong Kong and Calcutta, 1894-1897," Journal of the History of Medicine and Allied Sciences 52-1 (January 1997).

Xue Charlieq, Zou Han. Li Baihao, Hui Ka Chuen, "The shaping of Early Hong Kong: Transplantation and Adaptation by the British Professionals, 1841-1941," Planning Perspectives 27-4 (2012). 


\title{
Reorganizing Hospital Space: The 1894 Plague Epidemic in Hong Kong and the Germ Theory
}

\author{
Sihn Kyu-hwan*
}

This paper examined whether the preventive measures taken by the Hong Kong's colonial authorities were legitimate during the 1894 Hong Kong plague epidemic, and illuminated the correlation between the plague epidemic and hospital space in Hong Kong in the late 19th century. The quarantine measures taken by the colonial authorities were neither a clearcut victory for Western medicine nor for a rational quarantine based on scientific medical knowledge. Hong Kong's medical officials based on the miasma theory, and focused only on house-to-house inspections and forced quarantine or isolation, without encouraging people to wear masks and without conducting disinfection. Even after Hong Kong plague spread, the Hong Kong's colonial authorities were not interested in what plague bacilli were, but in where they were to be found and how to prevent and control an outbreak of the disease.

The germ theory brought significant changes to the disease classification

\footnotetext{
* Dept. of Medical History \& Institute for History of Medicine, College of Medicine, Yonsei University

E-mail: jerryq@yuhs.ac
}

Received: Oct. 09, 2016; Reviewed: Oct. 20, 2016; Accepted: Mar. 27, 2017 
Sihn Kyu-hwan : Reorganizing Hospital Space: The 1894 Plague Epidemic in Hong Kong and the Germ Theory

system. Until the 1890s, Hong Kong's colonial authority had classified cause of death mainly on the basis of symptoms, infectious diseases, parts of the body and diseases of systems. Microbiological analysis of the cause of death in Hong Kong was started by Hunter, a bacteriologist, in 1902. He used bacteriological tests with a microscope to analyze the cause of death. New disease recognition and medical recognition brought large changes to hospital space as well. In particular, from the 1880s to the early 1900s, Western medical circles witnessed shifts from miasma theory to the germ theory, thereby influencing Hong Kong's hospital spaces.

As the germ theory took ground in Hong Kong in 1894, the bacteriological laboratory and isolation ward became inevitable facilities, and hospital space were reorganized accordingly. However, the colonial authorities and local elites' strategy was different. As a government bacteriologist, Hunter established a central facility to unify several laboratories and to manage urban space from ouside the hospital. On the contrary, the Tungwah Hospital tried to transform hospital space with isolation ward and Receiving Ward System as the eclectic form of Chinese and Western medicine. The 1894 Hong Kong plague promoted the introduction of germ theory and the reorganization of hospital space.

Keywords: Hong Kong Plague Epidemic, Government Civil Hospital, Tungwah Hospital, Germ Theory, the Reorganization of Hospital Space, William Hunter 
